\title{
ИНФОРМАЦИОННОЕ СОПРОВОЖДЕНИЕ ДЕЯТЕЛЬНОСТИ МУЗЫКАЛЬНОГО ТЕАТРА «ВОЛКИ МИБУ»
}

Шаповалова Анастасия Анатольевна, бакалавр студент факультета коммуникативного менеджмента ФГБОУ ВО «Российский государственный сочииальный университет»

2. Москва

Научный руководитель:

Полунина Ольга Сергеевна, кандидат исторических наук ФГБОУ ВО «Российский государственный сочиальный университет» 2. Москва

Scientific supervisor:

\author{
Shapovalova Anastasia Anatolyevna, Bachelor \\ student of the Faculty of Communication Management \\ «Russian State Social University» \\ Moscow \\ Polunina Olga Sergeevna, \\ Candidate of Historical Sciences \\ «Russian State Social University»
}

Moscow

Введение

Аннотация. В данной статье исследуется проблема выведения бизнеса из финансового убытка и повышения охвата аудитории музыкального театра посредством развития официальных социальных сетей компании. С целью решения проблемы был составлен портрет целевой аудитории для обозначения стратегии публикации материалов, проведен SWOT-анализ социальных сетей организации, выявлен tone of voice компании для построения органичной коммуникации с аудиторией, разработан контент-план публикации материалов, начато продвижение театра в интернет-пространстве.

Abstract. This article explores the problem of removing a business from a financial loss and increasing the audience coverage of a musical theater through the development of official social networks of the company. In order to solve the problem, a portrait of the target audience was drawn up to indicate the strategy of publishing materials, a SWOT analysis of the organization's social networks was carried out, the tone of voice of the company was identified to build organic communication with the audience, a content plan for publishing materials was developed, and the theater was promoted in the Internet space.

Ключевые слова: продвижение деятельности, информационное сопровождение, социальные сети, публикация материалов, целевая аудитория, коммуникация.

Keywords: promotion of activities, information support, social networks, publication of materials, target audience, communication.

\section{Основная часть}

Журналистика - это многоуровневый термин, который имеет множество толкований и включает в себя не только сбор, обработку и передачу информации. Журналистика как профессия имеет комплексный характер, а сам журналист является универсальным, многофункциональным работником, который разбирается в основах иных специальностей, смежных с данной профессией. Таким образом журналист может быть одновременно фотографом, оператором, монтажером, звукорежиссером, копирайтером, PR-менеджером, работником прессслужбы и т.д.

В процессе проведения работы по продвижению организации студент-журналист опирался, в основном, на информацию, полученную в процессе прохождения учебных курсов «Интернет-маркетинг и интернетжурналистика», «Современные технологии рекламы, маркетинга и пиар» и «Современная пресс-служба в государственной, коммерческой и социальной сфере». То есть, на практике был применен симбиоз знаний в разных направлениях, однако, по сути, студент примерил на себя роль сотрудника пресс-службы. В соответствии с «Толковым словарем русского языка» С.И. Ожегова, пресс-служба - это отдел сбора и обработки информации по материалам печати. Однако профессия развивается, и ее сфера деятельности расширяется. В 
современном мире пресс-служба - это структура организации, осуществляющая процесс коммуникации между компанией, прессой и общественностью. В перечень обязанностей сотрудников пресс-службы входит в числе прочего входит также публикация внутренних новостей организации в социальных сетях и на официальном сайте компании.

Актуальность выбранной темы заключается в том, что социальные сети являются основными инструментами продвижения организаций, следовательно от грамотного подхода к ведению официальных аккаунтов компании зависит ее коммерческий успех компании, процент прироста целевой аудитории и возможность превзойти конкурентов.

Прежде чем создавать материалы для социальных сетей организации, стоит понимать, для кого мы ее публикуем. Для этого необходимо составить портрет целевой аудитории официальной группы во ВКонтакте (так как это основная интернет-платформа организации) и сегментировать ее по социально-демографическим признакам, психографическим признакам и личностным качествам.

В соответствии с социально-демографическими признаками возраст целевой аудитории колеблется от 20 до 50 лет (то есть, это молодежь и лица среднего возраста), преобладает женский пол, национальность - русские и русскоязычные жители стран СНГ. Психографические признаки: интересы - мюзиклы, спектакли, театральные представления, яркие сценические персонажи, классические сюжеты по мотивам истории и зарубежной литературы. Личностные качества - в результате анализа пользовательский комментариев можно сделать вывод о таких личностных качествах целевой аудитории, как дружелюбие, юмор, любознательность, творческое мышление, коммуникабельность, толерантность (поскольку своими действиями и внешним видом актеры театра затрагивают вопросы кроссдрессинга и определения гендерной идентичности, но аудитория относится к этому лояльно).

Обобщенный портрет целевой аудитории по результатам анализа - женщины молодого и среднего возраста, интересующиеся театральным искусством и позитивно относящиеся к теме кроссдрессинга.

Для того, чтобы выявить сильные и слабые стороны организации и понять, на какие аспекты следует обратить внимание, был проведен SWOT-анализ социальных сетей театра. В соответствии с пособием «Стратегический менеджмент» Н.H. Голивцовой, SWOT-анализ - это метод, который позволяет выявить сильные и слабые стороны фирмы, благоприятные возможности и угрозы. Результаты проведенного SWOTанализа указаны ниже в таблице.

\begin{tabular}{|c|c|}
\hline Сильные стороны & \\
\hline $\begin{array}{l}\text { 1. } \\
\text { театральных постановок. } \\
2 . \quad \text { Качественные спектакли. } \\
3 . \\
\text { постановок. } \\
4 . \quad \text { Лостоянное развитие и создание новых } \\
\text { проведения спектаклей. } \\
5 . \quad \text { Постоянная аудитория. } \\
6 . \quad \text { В каждом спектакле присутствуют активные } \\
\text { боевые сцены между главными героями, что } \\
\text { нетипично для музыкальных постановок. }\end{array}$ & $\begin{array}{l}\text { 1. } \\
\text { Возможности разных соцсетей в качестве } \\
\text { процентов. } \\
2 . \quad \text { Малая активность в социальных сетях, } \\
\text { отсутствие какого-либо PR-продвижения организации. } \\
3 . \quad \text { Маленькие залы и сцены. } \\
4 . \quad \text { Большой архив с видеозаписями концертов и } \\
\text { репетиций не используется. } \\
5 . \quad \text { Длительные перерывы между спектаклями } \\
\text { (один концерт в несколько месяцев). } \\
6 . \quad \text { Малая популярность мюзиклов не только } \\
\text { среди широких слоев общества, но и среди любителей } \\
\text { театрального искусства. }\end{array}$ \\
\hline Возможности & \\
\hline $\begin{array}{l}1 . \quad \text { Нетипичный театр, где все роли исполняют } \\
\text { женщины, может заинтересовать потенциальную } \\
\text { аудиторию своей исключительностью } \\
2 . \quad \text { Постоянное расширение театральной } \\
\text { программы спектакля, что может привлекать к себе } \\
\text { новых зрителей. } \\
3 . \quad \text { Креативные режиссеры, способные создать } \\
\text { интересные проекты. } \\
4 . \quad \text { Актеры не сосредоточены на коммерческой } \\
\text { выгоде, поэтому могут проводить благотворительные } \\
\text { концерты для демонстрации своей социальной } \\
\text { ответственности. }\end{array}$ & $\begin{array}{l}1 . \quad \text { Проблемы со здоровьем ведущих актеров. } \\
2 . \quad \text { Вероятность получить травму во время } \\
\text { выступлений и репетиций из-за активных действий и } \\
\text { неустойчивых сценических декораций. } \\
3 . \quad \text { Отрицательное отношение со стороны } \\
\text { зрителей, придерживающихся консервативных } \\
\text { взглядов. } \\
4 . \quad \text { Потеря интереса со стороны аудитории из-за } \\
\text { долгого отсутствия контента и спектаклей. } \\
\text { 5. } \quad \text { Очередная волна коронавируса, которая } \\
\text { может повлечь за собой закрытие театров/неполную } \\
\text { заполняемость зала. }\end{array}$ \\
\hline
\end{tabular}


В результате данного анализа можно сделать вывод, что организации первостепенно следует чаще обновлять контент в социальных сетях и чаще проводить концерты и мероприятия, чтобы целевая аудитория не потеряла к театру интерес.

Чтобы органично взаимодействовать с целевой аудиторией от имени театра, следует проанализировать tone of voice организации и воспроизводить его в последующих публикациях. Tone of voice - это стиль взаимодействия бренда с целевой аудиторией во всех каналах коммуникации. От этого критерия зависит, как бренд будет восприниматься потребителями: как близкий друг, учитель, провокатор. Tone of voice театра «Волки Мибу» - информативный, официальный, дружелюбный, вежливый. В каждой публикации присутствует обращение «дорогие друзья» или «дорогие зрители», к аудитории театр обращается исключительно на «вы», не используются сленговые выражения. Tone of voice организации можно классифицировать как «официальный представитель театра».

Для облегчения публикации материалов необходимо составить контент-план на определенный период и придерживаться его в дальнейшем. Контент-план - это структурированный график публикаций материала для сайтов/блогов/социальных сетей. Таким образом, придерживаясь подобного графика, можно выложить весь необходимый контент и не запутаться во времени публикации или в том, в какую социальную сеть должен попасть тот или иной материал. Ниже приведен пример контент-плана публикации материалов для музыкального театра «Волки Мибу», составленного на месяц.
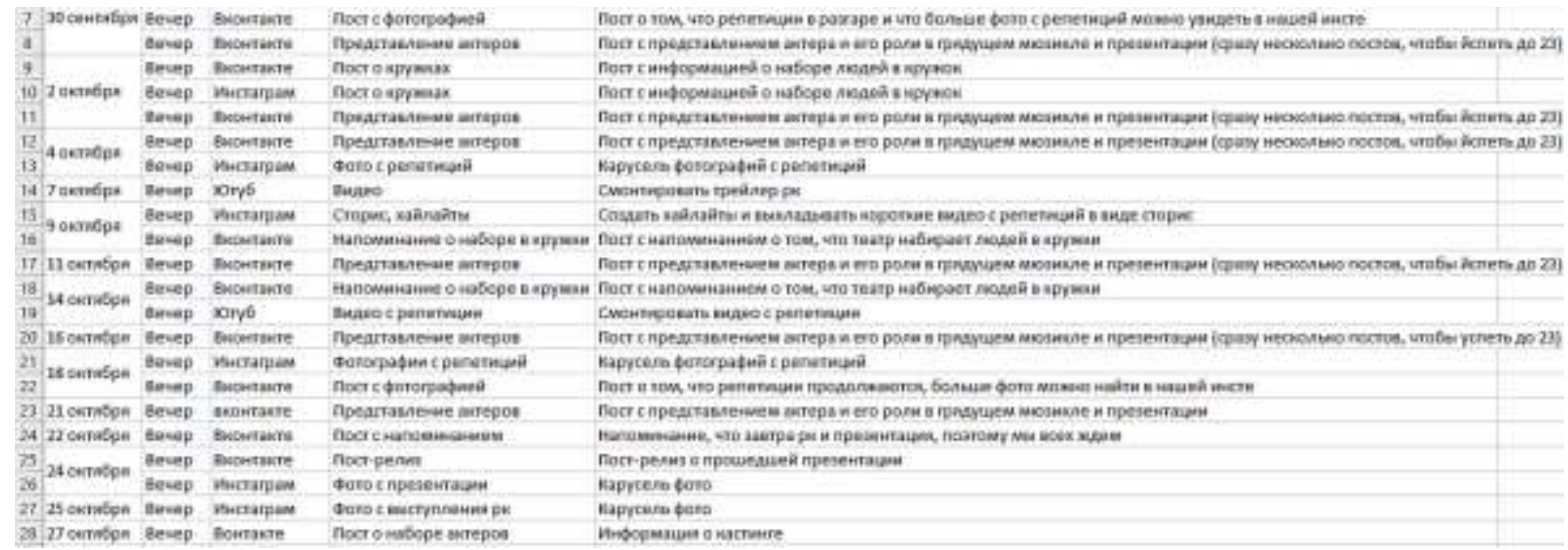

На основе составления портрета целевой аудитории и SWOT-анализа социальной сети ВКонтакте складывается более четкое понимание того, какие новости и публикации вероятнее всего могут заинтересовать пользователей. Было выделено несколько типов постов: развлекательный контент - публикации о репетициях театра, публикации о выступлениях театра, юмористический фото- и видеоконтент; информационный контент расписание концертов, афиша театра, организационная информация. После проведения всех исследований и анализов началась публикация материалов.

\section{Заключение}

Несмотря на проведенные исследования, выведенная стратегия продвижения организации не принесла ожидаемых результатов. Охват целевой аудитории организации увеличился незначительно, что, в свою очередь, никак не отразилось на доходах компании.

По результатам ведения социальных сетей организации в течение 3 месяцев можно сделать вывод, что исключительно публикации контента в официальных аккаунтах организации недостаточно, чтобы повысить охват целевой аудитории и вывести бизнес из финансового убытка.

Таким образом, чтобы выйти за пределы своих социальных сетей, следует пересмотреть стратегию продвижения компании, организовать несколько нетипичных для организации мероприятий, добиться позитивных упоминаний в СМИ для достижения поставленных целей и задач.

Список источников и литературы:

1. Антипов, К. В. Основы рекламы. - М.: Дашков и К, 2009.

2. Блюм М.А., Молоткова Н.В. Основы использования средств рекламы в коммерческой деятельности: учебное пособие / Тамбов: Тамб. гос. техн. университета, 2006.

3. Голивцова Н.Н. Стратегический менеджмент: учебно-практическое пособие/ВШТЭ СПбГУПТД- СПб., 2016.

4. Иванов, А. А. / Брендинг: учеб. пособие. - Комсомольск-на-Амуре: ФГБОУ ВПО «КнАГТУ», 2013.

5. Корконосенко С.Г. / Основы журналистики: Учебник для вузов - М.: Аспект Пресс, 2004. 
6. Ожегов С.И., Толковый словарь русского языка: 100000 слов, терминов и выражений: [новое издание], под общ. ред. Л. И. Скворцова. - 28-е изд., перераб. - Москва: Мир и образование, 2015.

7. Шевченко Д.А., Шевченко Д.Д. «Цифровой маркетинг-микс», Интеллектуальная издательская система Ridero, 2021. 